IOSR Journal of Pharmacy

ISSN: 2250-3013, www.iosrphr.org

\||| Volume 2 Issue 4 \||| July-August 2012 ||| PP.43-46

\title{
Socio demographic factors affecting perinatal mortality- A study in a rural setup
}

\author{
Tayade Surekha A ${ }^{1}$, Naina Kumar ${ }^{2}$ \\ ${ }^{1}$ Professor, ${ }^{2}$ Assistant Professor Departments of Obstetrics and Gynecology, Mahatma Gandhi Institute of \\ Medical Sciences, Sewagram
}

\begin{abstract}
Background:- Perinatal mortality is a sensitive indicator of the quality of services provided to pregnant women and their newborn. Perinatal mortality audit in a health care facility helps to determine the important cause of perinatal deaths and take measures to reduce it. This study was carried out to find out the socio demographic causes of perinatal deaths.

Material and Methods: - A clinical observational study was undertaken at a tertiary care teaching hospital in a rural area over a period of 1 year from October 2010 and September 2011.

Results:-The perinatal mortality rate was found to be 17.07 per 1000 live births. Early age at pregnancy, illiteracy, rural residence and poor socioeconomic status was commonly associated with higher perinatal deaths. Other factors directly contributing to perinatal deaths were unbooked status, low and high birth order pregnancy and occupation of parents.

Conclusion:- Effective measures to reduce perinatal mortality need to be started well before the birth of a child by concentrating on education status of women, improving the paying capacity of the couple by providing employment and improving health care delivery system in rural area.
\end{abstract}

Keywords: PERINATAL MORTALITY, SOCIO DEMOGRAPHIC FACTORS, RURAL AREA

\section{INTRODUCTION}

Of the estimated 130 million infants born each year worldwide, 4 million die in the first 28 days of life [1]. Three-quarters of neonatal deaths occur in the first week and more than one-quarter occur in the first 24 hours $[1,2]$. Neonatal deaths and stillbirths stem from poor maternal health, inadequate care during pregnancy, inappropriate management of complications during pregnancy and delivery, poor hygiene during delivery and the first critical hour after birth and lack of newborn care. Several factors such as women's status in society, their nutritional status at the time of conception, early childbearing, too many closely spaced pregnancies and harmful practices, such as inadequate cord care, letting the baby stay wet and cold, discarding colostrum and feeding other food, are deeply rooted in the cultural fabric of societies and interact in ways that are not always clearly understood [2]. While developed countries have seen dramatic decline in perinatal mortality because of investments in reproductive health and socio-economic conditions, corresponding progress in low income countries has been slow [3].

Perinatal mortality audit in an institution helps to find out not only the status of quality of services but also helps to determine the important cause of perinatal deaths and take measures to reduce it. This study was done in a tertiary care centre in a rural area to study the socio-demographic factors affecting perinatal mortality.

\section{MATERIAL AND METHODS}

A retrospective observational study was carried out in department of Obstetrics and Gynecology of a tertiary care medical institute of central India. The hospital caters to rural population and annually 5000 deliveries are conducted here. We evaluated perinatal mortality for all births at Kasturba Hospital, Sewagram for a period of 1 year from October 2010 to September 2011. All perinatal deaths after 22 weeks of gestation were included in the study. A predesigned proforma and case definitions for data collection was developed. Maternal age, parity, place of residence, literacy, family income, socioeconomic status, occupation and booked/unbooked status were the parameters that were looked into. Statistical analysis was done by Stata 10 software and results expressed in percentages and proportion. Ethical clearance was obtained from institutional ethical committee.

\section{RESULTS}

Between October 2010 and September 2011, there were 5,672 live births at Kasturba hospital with 84 stillbirths, 14 intrapartum deaths and 86 early neonatal deaths, making a total of 184 perinatal deaths. The perinatal mortality rate was found to be 17.07 per 1000 births for this period. If we look into the maternal factors 
maximum 103(55.97\%) perinatal deaths occurred in the age group of 19-24 years and $105(56.52 \%)$ women were primipara. Rural area of residence was found in $133(72.28 \%)$ and urban in 51(27.71\%). According to Kuppuswami's classification of socioeconomic status $133(72.28 \%)$ belonged to lower class and none of the women belonged to the upper middle or upper social class. For the 184 perinatal deaths $86(46.73 \%)$ women were landless labourers, 18(9.78\%) were cultivators, 66(35.86\%) did household work and 14(7.60\%) had government/non government jobs. Maximum 104 (56.52\%) women were illiterate, 38(20.65\%) had primary education, 39(21.19\%) secondary education, 2(1.08\%) were graduates and 1(0.54\%) postgraduate. Only $59(32.06 \%)$ were booked cases and the remaining 125(67.93\%) were un booked. Details of the results are shown in table 1 .

Table 1 showing socio-demographic characteristics affecting perinatal mortality

\begin{tabular}{|c|c|c|c|c|c|}
\hline Determinant & IUD & $\begin{array}{l}\text { Intrapartum } \\
\text { death }\end{array}$ & $\begin{array}{l}\text { Neonatal } \\
\text { death }\end{array}$ & Total & P value \\
\hline $\begin{array}{l}\text { Age } \\
<19 \text { yrs } \\
19-24 \text { yrs } \\
25-29 \text { yrs } \\
30-34 \text { yrs } \\
35 \text { yrs \& above } \\
\end{array}$ & $\begin{array}{l}14(7.60 \%) \\
44(23.91 \%) \\
10(5.43 \%) \\
7(38.04 \%) \\
5(2.71 \%)\end{array}$ & $\begin{array}{l}2(1.08 \%) \\
8(4.34 \%) \\
3(1.63 \%) \\
1(0.54 \%) \\
0\end{array}$ & $\begin{array}{l}11(5.97 \%) \\
41(22.28 \%) \\
12(6.52 \%) \\
10(5.43 \%) \\
6(3.26 \%)\end{array}$ & $\begin{array}{l}27(14.67 \%) \\
103(55.97 \%) \\
25(13.58 \%) \\
18(9.78 \%) \\
11(5.97 \%)\end{array}$ & $<0.05$ \\
\hline $\begin{array}{l}\text { Parity } \\
\text { Primi } \\
\text { Multigravida(2-4) } \\
\text { Grandmulti(>4) }\end{array}$ & $\begin{array}{l}42(22.82 \%) \\
39(21.19 \%) \\
3(1.63 \%)\end{array}$ & $\begin{array}{l}10(5.43 \%) \\
4(2.17 \% \\
0\end{array}$ & $\begin{array}{l}52(28.26 \%) \\
29(15.76 \%) \\
5(2.71 \%)\end{array}$ & $\begin{array}{l}104(56.52 \%) \\
72(39.13 \%) \\
8(4.34 \%)\end{array}$ & $<0.05$ \\
\hline $\begin{array}{l}\text { Place of residence } \\
\text { Urban } \\
\text { Rural }\end{array}$ & $\begin{array}{l}39(21.19 \%) \\
45(24.45 \%)\end{array}$ & $\begin{array}{c}03(1.63 \%) \\
11(5.97 \%)\end{array}$ & $\begin{array}{l}09(4.89 \%) \\
77(41.84 \%)\end{array}$ & $\begin{array}{l}51(27.71 \%) \\
133(72.28 \%)\end{array}$ & $<0.001$ \\
\hline $\begin{array}{l}\text { Socioeconomic } \\
\text { status } \\
\text { Upper (I) } \\
\text { Upper middle (II) } \\
\text { Lower middle (III) } \\
\text { Upper lower (IV) } \\
\text { Lower (V) }\end{array}$ & $\begin{array}{l}0 \\
0 \\
6(3.26 \%) \\
16(8.69 \%) \\
62(33.69 \%)\end{array}$ & $\begin{array}{l}0 \\
0 \\
1(0.54 \%) \\
4(2.17 \%) \\
9(4.89 \%)\end{array}$ & $\begin{array}{l}0 \\
0 \\
6(3.26 \%) \\
18(9.78 \%) \\
62(33.69)\end{array}$ & $\begin{array}{l}0 \\
0 \\
13(7.06 \%) \\
38(20.65 \%) \\
133(72.28 \%)\end{array}$ & $<0.001$ \\
\hline $\begin{array}{l}\text { Occupation } \\
\text { Landless labourers } \\
\text { Cultivators } \\
\text { Household work } \\
\text { Service }\end{array}$ & $\begin{array}{l}41(22.28 \%) \\
7(8.69 \%) \\
30(16.30 \%) \\
6(3.26 \%) \\
\end{array}$ & $\begin{array}{l}7(3.80 \%) \\
3(1.63 \%) \\
4(2.17 \%) \\
0\end{array}$ & $\begin{array}{l}38(20.65 \%) \\
8(4.34 \%) \\
32(17.39 \%) \\
8(4.34 \%) \\
\end{array}$ & $\begin{array}{l}86(46.73 \%) \\
18(9.78 \%) \\
66(35.86 \%) \\
14(7.60 \%) \\
\end{array}$ & $>0.05$ \\
\hline $\begin{array}{l}\text { Literacy } \\
\text { Illiterate } \\
\text { Primary education } \\
\text { Secondary education } \\
\text { Graduate } \\
\text { Postgraduate }\end{array}$ & $\begin{array}{l}47(25.54 \%) \\
18(9.78 \% 0 \\
17(9.23 \%) \\
1(0.54 \%) \\
1(0.54 \%) \\
\end{array}$ & $\begin{array}{l}7(3.80) \\
3(1.63 \%) \\
4(2.17 \%) \\
0 \\
0 \\
\end{array}$ & $\begin{array}{l}50(21.17 \%) \\
17(9.23 \%) \\
18(9.785) \\
1(0.54 \%) \\
0\end{array}$ & $\begin{array}{l}104(56.52 \%) \\
38(20.65 \%) \\
39(21.19 \%) \\
2(1.08 \%) \\
1(0.54 \%) \\
\end{array}$ & $<0.01$ \\
\hline $\begin{array}{l}\text { Booked } \\
\text { Unbooked }\end{array}$ & $\begin{array}{l}25(13.58 \%) \\
59(32.06 \%)\end{array}$ & $\begin{array}{l}06(3.26 \%) \\
08(4.34 \%)\end{array}$ & $\begin{array}{l}28(15.21 \%) \\
58(31.2 \%)\end{array}$ & $\begin{array}{l}59(32.06 \%) \\
125(67.93 \%)\end{array}$ & $<0.01$ \\
\hline
\end{tabular}




\section{DISCUSSION}

With the decline in infant mortality rate to low levels in many developed countries, perinatal mortality has assumed greater significance as a yardstick of obstetric and paediatric care before and around the time of birth. Although perinatal period occupies less than $0.5 \%$ of the average life span there are more deaths in this period than during the next $30-40$ years of life in many developing countries [4]. Perinatal mortality is a sensitive indicator of the quality of services provided to pregnant women and their newborn. It is associated with a number of socio demographic indicators such as ethnic groups, family income, unemployment, mothers or father's social class and education of the mother [5]. Moreover, it is known that infant mortality tends to be higher in countries with greater social and health-related inequalities and tends to rise in countries that have suffered from substantial socioeconomic, cultural and political disruption [6]. High maternal age, primi-parity, high parity, smoking, low socio-economic status, being a single mother have also been identified as risk factors for perinatal mortality [7].

In the present study the perinatal mortality rate was found to be 17.07 per 1000 live births. The 1997 Sample Registration System (SRS) of India reported the perinatal mortality to be 32.5 per thousand live births [7]. A study done in Punjab in the year 1996, reported the perinatal mortality to be 37.5 per thousand live births [8]. Dasgupta reported a PMR of 67.7 per 1000 live births [3]. Age of the mother at pregnancy is a good determinant of perinatal and neonatal mortality. Children born to mothers at either a very young or very old reproductive age group are found less likely to survive. Teenage mothers are often biologically, socially, emotionally and economically ill prepared for child bearing. A short birth interval too is a health risk. Children born to mothers with a short inter pregnancy interval are at a greater risk of dying, in both rural and urban areas [9]. In the present study maximum number of deaths occurred in babies born to mothers below the age of 24 years. It has been well documented that NNM and PNM increase as we go down the social ladder. Historically, an inverse relation between social class and stillbirth rates was reported [10]. This association between low socioeconomic level and mortality has been noted in several international studies [11,12]. Women's literacy and level of education has repeatedly shown influence on the risk of perinatal deaths[13,14].A study in 1955 observed the influence of social class and geographical location on stillbirths and neonatal mortality in England and Wales [15].A similar study conducted to assess trends in fertility and infant mortality rates in Leon, Nicaragua, observed that the decline in infant mortality rate was due to health interventions, specially targeted to poorer groups of women and their infants [16]. Education status of mother's literacy too had impact on the survival of the perinate. In a study the odds of having a death in a family where the mother was illiterate was 4.04 times than in a family where the mother was literate. (95\% CL: 2.40-7.42) [7].Mothers with an educational level less than class 5 had a 3.05 times increased risk of having a PN/NNM as compared to those with a higher level of education [7].

In this study perinatal mortality was high in woman from rural area (72.28\%) as compared to urban area $(51(27.71 \%)$. Similar findings were found by other researchers $[5,17]$. This is probably because urban women have better access to health care services, emergency obstetric care and essential newborn care. Skilled care at delivery has been associated with lower neonatal death rates [18]. Unbooked status also increases the risk of perinatal mortality as has been documented by this study. Similar findings have been reported by Razeo Korejo (72\% in unbooked and $28 \%$ in booked) from Pakistan. Women visiting a health care facility, antenally at least 3 times, usually gets investigated for commom obstetrical and medical problems and thus high risk factors get identified and managed, reducing the risk of prenatal mortality.

\section{CONCLUSION}

The chances of survival of a neonate begin well before birth. The causes attributable to perinatal mortality comprised of various social problems like age of mother, birth order, place of residence, occupation and socioeconomic status. Socially and economically marginalized households are at a higher risk of having a perinatal death. A higher educational level of the parents and an occupation with a steady source of income was found to be protective for the survival of the neonate. Effective measures to reduce perinatal mortality need to be started well before the birth of a child by concentrating on education status of women, improving the paying capacity of the couple by providing employment and improving health care delivery system in rural area. To save newborns in India, we need to change our focus to the time when most infants die i.e.the perinatal and neonatal period. We also need to shift our attention from hospitals to the communities where deaths occur. 


\section{REFERENCES}

[1]. World health report 2005: Make every mother and child count. Geneva: WHO; 2005.

[2]. Lawn JE, Cousens S, Zupan J. 4 million neonatal deaths: When? Where? Why? Lancet 2005; 365: 891-900 doi: 10.1016/S01406736(05)71048-5 pmid: 15752534.

[3]. Dasgupta S, Saha I, Lahiri A, Mandal AK. A study of perinatal mortality and associated maternal profile in a medical college hospital. J Indian Med Assoc. 1997 Mar; 95(3):78-9.

[4]. Meredith Davis JB. Community Health, Preventive Medicine and Social Services. 5th ed. Bailliere Tindall; 1983.

[5]. Katarina R, Andrea M G, Jitse P. van Dijk , Kollarova J, Rosic M, Groothoff J. Regional socioeconomic indicators and ethnicity as predictors of regional infant mortality rate in Slovakia Int J Public Health , 2011 56:523-531

[6]. Zatonski W, Mikucka M, La Vecchia C, Boyle P .Infant mortality in Central Europe: effects of transition. Gac Sanit,2006 ;20:63-66

[7]. Joshi R. Perinatal and neonatalMortality in rural Punjab-A community based case-control study. Working paper series. Working Paper No. 3 August 2003

[8]. Sachar RK and Soni RK. Perinatal mortality in rural Punjab - a population based study. J Trop Pediatr 2000; 46(1):43-45.

[9]. Galway K, Wolff B and Strugus R, editors. Child survival: Risks and the road to health. Westinghouse: Institute for resource development; 1987

[10]. Baird D. The influence of social and economic factors on stillbirths and neonatal deaths. J Obstet Gynaecol Br Emp 1945;5:21734.

[11]. Townsend P and Davidson N. Inequalities in health: The Black Report. Harmondsworth: Penguin; 1982

[12]. Ben-Shlomo Y, White IR and Marmot M. Does the variation in socioeconomic characteristics of an area affect mortality? Br Med J 1996; 312:1013 -14.

[13]. Caldwell J and Mc Donald P. Influence of Maternal Education on infant and child mortality: levels and causes. Health Policy Educ 1982; 2:251-256.

[14]. Arntzen A, Moum T, Magnum P and Bakketeig LS: The association between maternal education and post neonatal mortality: trends in Norway 196 -91.Int J Epidemiol1996; 25-578-584.

[15]. Campbell AGM and Mcintosh N, editors. Forfar and Arneil's textbook of Paediatrics, Social Paediatrics. ELBS with Churchill Livingston; 1994

[16]. Pena R, Liljestrand E, Zelaya E and Persson L. Fertility and infant mortality trends in Nicaragua 1964-1993: The role of women's education. J Epidemiol Community Health 1999;53:132-137

[17]. Abdoulaye H D, Nicolas M, Emmanuel Z, Halvor S, Simon C, Thorkild T. Perinatal mortality in rural Burkina Faso:a prospective community-based cohort study. BMC Pregnancy and Childbirth 2010, 10:45

[18]. World Health Organization. Making Pregnancy Safer. RHR00.6. Geneva: WHO; 2000.

[19]. Korejo R, Bhutta S, Noorani K, Bhutta Z. An audit and trends of perinatal mortality at the Jinnah Postgraduate Medical Centre, Karachi J Pak Med Assoc, 2007 April; 57( 4) :168-17 